\title{
Hegemony for Local Politics Settlement in Murung Raya Regency
}

\author{
Siti Mauliana Hairini ${ }^{1}$, Rahmat Hidayat ${ }^{2}$ \\ \{yanahairini@gmail.com¹, hidayatrhm233@gmail.com²\}
}

Government Sciences Department, Faculty of Social and Political Sciences, Universitas Lambung Mangkurat, Jl. Brigjend H. Hasan Basri, Banjarmasin, South of Kalimantan, Indonesia ${ }^{1,2}$

\begin{abstract}
The fall of Soeharto has begun the political reformation in Indonesia which bring the division of power from national to local level. Democratization in local level has been transformed to by law No. 22/99 to the law of No. 32/2004. People's political right has developed to choose directly their own leader for their local government which has believed as the best way to get the best leader for local people. In the other hand, political reform makes the elites in local level has to change their strategy to hold the power to stay on their hand. Mostly the study about democracy especially in developing country has been showed the phenomena about oligarchy, politics of clan, and political dynasty. But this research wants to show that oligarchy, politics of clans, even political dynasty is only a product of "hegemony" which modified the democracy to be controlled terrain. Hegemony and democracy is the perfect match to dominate power without conflict, and for local elites it's the best way to make a settlement of power in local government by hegemonic local people. This research used qualitative method with study cased approach which located in Murung Raya Regency. Key informants were Regent, Deputy Regent, Community leaders, and the winning team of elected Regent in Murung Raya Regency. The results were showed that the hegemony has started by political consensus between elites in politics and community of Murung Raya. Hegemony also used mediator to spreads discourses to support local elite in Murung Raya governance. And also, Culture and political compromise has used to controlled people and handling the power. In the end, hegemony is not only about the inculcation of meaning and values by intellectual and cultural techniques but also by emotional ties, empathy, and love which gradually embedded by the elites.
\end{abstract}

Keywords: Hegemony, Democracy, Local Politics

\section{Introduction}

The transition of political system from autocracy to democracy has been impact to the way of rule of country. In autocracy, state was rule by one person or small group of persons and has to change by democracy system that ask to "the rule of the people". The transition of power has started by mutual agreement on the rules that was concerning to do competition for office and influence. People are managed to agree with the form of democracy as appropriate concept for society and legitimate for government polity.

Democratic elements - such as competitive elections, respect for civil liberties, and actors' commitment to democracy as the only viable channels for political transition[1]. Democratization should be understood not solely as a national-level phenomenon, [2] has been 
argued that each country has a varying degree of democratic contestation and inclusiveness even in national and subnational level for state and also in the social organizational levels.

In Indonesia, the fall of Suharto in 1998 has led to various institutional changes and remodeling the relationship between central and regional government. In a very short period of time, Indonesia has been remodeled from very centralized to one of the most decentralized countries in the world [1]. In the period of 1999-2004, the rule of law number 22/1999 has been order that the local head of government (governor and regent/ mayor) was selected by the local DPRD. The superior power of the DPRD to elect the local government had bring another problem like money politics, less of accountability to people and lack of legitimacy to local government. In 2004, to improve the accountability and the legitimacy of the local leaders, the Megawati administration introduced direct local elections for head of government at the provincial and district/ municipal levels by the rule of law number 32/2004[1].

The transformation of rules and design of local election especially in Indonesia has been change the strategy of elites in subnational level to compete and get the vote from society. The democracy transformation in subnational level in Indonesia was challenged the political elites to made domination with compromise or what Gramsci called in Hegemony. The direct election in subnational level was not only to strengthen local democracy but also giving the agreement of society to the ruler of local government. People vote in election was one of the manifested of the agreement of society to be ruled.

In the literature on elites in democracy, mostly showed the existence of oligarchy in a democratic society [3][4] defines oligarchy as a "wealth defense mechanism". In some literature of oligarchy in democracy explain that family ties become the primary elite selection mechanism to protect the incumbent's interests[5][6][7]. This paper fills the gap by arguing the transformation of local democracy by direct election has been force the political elites to take strategy by doing "Hegemony" to get the agreement of people as subordinate side. The study case of this paper was the hegemony strategy of ruling elites in Murung Raya Regency which located in centre Kalimantan of Indonesia.

Murung Raya Regency has been formed into a new definitive district dated July 2, 2002. and the first Regent of Murung Raya Regency for 2002-2003 was Drs. Romansyah Bagan. But from 2003-2008 and 2008-2013 period, Ir. Willy M. Yoseph, MM has been ruled as elected Regent of Murung Raya Regency. In 2013, Drs. Perdie, MA as the younger brother of Ir. Willy M. Yoseph has elected as Regent of Murung Raya regency for 2013-2018 period. In 2018, through direct elections Drs. Perdie, MA was re-elected to be the number one people in Murung Raya government. For decades, the majority people in Murung Raya Regency has agreed to the domination of the brother of Willy M Yoseph and Drs. Perdie.,MA and their relative in political power of Murung Raya. The process of legitimate domination by rulling elites in Murung Raya to local people makes a study of "Hegemony of local elites for political settlement in subnational Democracy of Murung Raya Regency" needs to be investigated more deeply.

\section{Research Method}

The research method used in this study is qualitative study with case study approach[8], [9]. Case studies are used to delve deeper information about the case of the Hegemony of local elites for political settlement in subnational Democracy of Murung Raya Regency. There are three rationalities why the author used case study methods. First, Murung Raya was the regency with the domination with less of resistances. Second, Murung Raya was the regent which 
produce an oligarchy by minority group of religious belief. Third, Murung Raya oligarchy of local elites already have gotten the vote from people for three times in a row. This study was conducted in Murung Raya District, located in Central Kalimantan Province. This study has interviewed 15 persons as representatives from Murung Raya Government from regent, vice regent, chief of departments in Murung Raya Government, representatives of society, winning team, and political party. There are three steps in finding data which used desk study, in depth interview, and according archives. The multiple sources of evidence aim to give researchers the opportunity to focus on broader historical issues, attitudes, and observations.

\section{Result and Discussion}

The hegemony in local politics of Murung Raya was a strategy of power to build an oligarchy of rulling elites by political dynasty in subnational level of government. In democracy concept has defined the government of people which means the government should has the approval by society. In hegemony, the domination of power was beginning with the agreement and consensus from society to elites. the brother of Ir. Willy M Yoseph,M.M and Drs. Perdie M Yoseph has win 3 times of pilkada and ruled Murung Raya for more than 15 years as "Ruling Elites". They have used the strategy of domination less of risk or what Gramsci called was "hegemony". This study has been found that the process of "Hegemony for local politics settlement in Murung Raya Regency" was begin with consensus for conflict prevention, then legitimacy for oligarchy, and the last hegemony for harmonization strategy for local politics in Murung Raya Regency.

\subsection{Consensus for Conflict Prevention}

Huntington believes that democracy provides a shared framework by which conflicting interests are mediated. In addition, Conflicts within democratic politics involves competition among the various groupings in a society to turn state power to their own ends. Even democracies have served the idea about consensus between majority and minority in making policies, but in this study, consensus has been used for political deals between ruling elites and community elites.

In hegemony, consensus becomes something very important, it can be said that consensus is the door to the formation of greater hegemony, even public acceptance of a hegemony can be in the form of a consensus, both formal and non-formal consensus. Murung Raya Regency have fulfilled by heterogeneous people with diverse local entities, so as ruling elites in democratic system the authority and power were nothing without people legitimation.

In Murung Raya Regency, consensus was the key that always brings victory in every local election. The interviewed with H. Darmaji., SE as the chairman of the Partai Amanat NAsional (PAN) in Murung Raya representative's office, has said: "the coalition has begun before the election period, but the political communication was built from long time ago, like direct meeting and via telephone. The communications become more intense when survey data has shown that Perdie has high surveys. Those data were the reason of coalition and consensus to give mutual beneficial for us. "(Interview on January 4th, 2019)

The willingness to build consensus (coalition) with ruling elites is based on an awareness of personal interests that can get beneficial and profit. Based on existing calculations and good 
communication reasons, consensus is a political reality that must be taken at that time. The ruling elite was made the consensus with some alliance of community groups. For more details, see the following table:

Table 1. Consensus among Ruliing Elites and Community elites

\begin{tabular}{lll}
\hline Name & Consensus & Outcomes \\
\hline Alfi Hadi (2019) & Get facilities for business & $\begin{array}{l}\text { Got project for cheap } \\
\text { housing for 25 units in } \\
\text { Mangkahui village }\end{array}$ \\
Ahmad Ma'ruf (2018) & Got position to be "Lurah" & $\begin{array}{l}\text { Has been promoted } \\
\text { become "lurah" }\end{array}$ \\
H. Supriadi (2018) & $\begin{array}{l}\text { Was promised to be leader for Laung } \\
\text { Tuhup Sub-district }\end{array}$ & $\begin{array}{l}\text { Has been promoted as } \\
\text { leader for Laung Tuhup } \\
\text { Sub-district }\end{array}$ \\
Alamsyah (2018) & Got facilitated for business & Got the project without PE \\
\hline
\end{tabular}

Source: Primary researcher data

Ruling elites has always made consensus and do embrace with some figures in society and even their political "enemies" to join the power group. Those strategy was aims to minimize resistance and weaken enemy forces. "Beangkat Hampahari" was a strategy of ruling elites to embrace their political enemies. Consensus among the elites in Murung Raya Regency was an effort to make local entities feel part of the government, to minimize conflict and prevent resistance to their local government. Therefore, in every election period and regional government period they always present representations from various local entities in the Murung Raya district to maximize their chances of winning in the existing political competition.

\subsection{Legitimacy for Oligarchy}

Legitimacy of the ruling elite is obtained through the fulfilment of discourse developed in the society especially for infrastructure development. The discourse has been leaded the community paradigm into rational thinking as produced by ruling elites. The discourse was intended people to prevent subjective views, especially political relation based on racial and prefer to seek the political leader based on their objectivity which based on the ability of the government that focusing on governance business and development in Murung Raya Regency. For clarity, there's some pictures of infrastructure that was built during the leadership of the ruling elites in Murung Raya.

Table 2. Infrastructure That Built in Murung Raya Since 2003-2019

\begin{tabular}{lll}
\hline Construction & Location & years \\
\hline Murung Raya Merdeka Bridge & Puruk Cahu & 2008
\end{tabular}


Willy M Yoseph Stadium

Office region for local government of Murung Raya

Kristian Center

Mesjid Agung

Bundaran Emas

Sapan Garden

Repairment Muara streets

New Airport Residential

Road Repairment in Hill Area

Hospital

Hilir Market
Puruk Cahu

2013

Puruk Cahu

2006

Puruk Cahu

2010

Puruk Cahu

2015

Puruk Cahu

Puruk Cahu

Laung Tuhup Sub-district and Barito Tuhup Raya Sub-district

Puruk Cahu

Tanah siang, Tanah siang Selatan, Murung

$2015, \quad 2016$

and 2017

Puruk Cahu

2005

Puruk Cahu

Source: Primary researcher data

Development in Murung Raya Regency during the period of Ir. Willy M Yoseph,M.M and Drs. Perdie M Yoseph's leadership as the ruling elite since 2003-now has become evidence of the suitability of discourse and evidence of their success in leading the regional government of Murung Raya Regency. The development of infrastructure has a legitimate impact for the ruling class and the discourse that emphasizes objectivity to the capabilities and development of leaders without looking at their racism has strengthened their position as the ruling elite.

\subsection{Hegemony, harmonization, and settlement for local politics in Murung Raya Regency}

Hegemony according to Antonio Gramsci is social and political control through the dominance of power that can be accepted by the people [10][11][12][13]. In other words, this study wants to show that Hegemony is the domination of the people through the harmonization of power. In Murung Raya Hegemony and Harmonization was begin with the concept of consensus among elites and local people. Consensus also was the effective way to decrease the competition in political arena. Before Pilkada 2018, there were so many figures who had wanted to become leaders of the Murung Raya Regency and become challenger of the incumbent. After the consensus, some figures preferred not to be involved in the 2018 elections after their desire to become regent candidates could not be realized. 
Table 3. Figures list that canceled to be candidates in Pilkada of Murung Raya

\begin{tabular}{|c|c|c|}
\hline Figures & Desires & Decision \\
\hline H.Mulyar & Candidates of regent & Preferred to not involve in Pilkada \\
\hline Rumiadi & Candidates of vice regent & Become winning team of incumbent \\
\hline Rahmanto Muhidin & Candidates of vice regent & $\begin{array}{l}\text { Coordinator of incumbents winning } \\
\text { team. }\end{array}$ \\
\hline Yetro Midel Yoseph & Candidates of regent & $\begin{array}{l}\text { Coordinator of logistic for } \\
\text { incumbents winning team. }\end{array}$ \\
\hline Gad F Silam & Candidates of regent & $\begin{array}{l}\text { Chief of Winning team for } \\
\text { Incumbents. }\end{array}$ \\
\hline Sirajul Rahman & Candidates of regent & $\begin{array}{l}\text { Chief of Winning team for } \\
\text { challenger. }\end{array}$ \\
\hline Rezekinnor & Candidates of regent & $\begin{array}{l}\text { Be Vice Regent candidate for } \\
\text { Incumbent of Regent. }\end{array}$ \\
\hline Susilo & Candidates of regent & $\begin{array}{l}\text { Be Vice Regent candidate for } \\
\text { challenger of incumbent Regent. }\end{array}$ \\
\hline Darmaji & Candidates of regent & Preferred to not involve in Pilkada \\
\hline
\end{tabular}

Source: Primary researcher data

Hegemony through consensus was a manifestation that show even the ruling elites need to realize that their interests can only be accommodated if supported by other individuals and by other groups. Hegemony in Murung Raya try united by ideas, as well as ideologies and they also embrace more people which not only figure in personal but also make big coalition among political party in Murung Raya.

Table 4. Coalition list of Ruling Elite that always win for Pilkada Murung Raya

\begin{tabular}{lll}
\hline Elected Candidates in Pilkada & Year & Political Parties Coalition \\
\hline $\begin{array}{l}\text { Ir. Willy M Yoseph,M.M } \\
\text { Drs.H. Nuryakin }\end{array}$ & 2008 & PDIP, PPP, GOLKAR \\
& & \\
Drs. Perdie M Yoseph & 2013 & PDIP, PAN,HANURA, \\
Darmaji, S.E. & & GERINDRA, PKP,PKB \\
Drs. Perdie M Yoseph & & PDS, PMD,PBB \\
Rejekinoor, S.Sos & 2018 & PDIP, NASDEM,PPP, PKB, \\
& & HANURA,PSI
\end{tabular}

Source: Primary researcher data 
The consensus between the elites with other political elites has been influences the form of consensus for the community to the political elite. Consensus has showed by pragmatic promises such as providing resources and access to power and office. Besides that, the use of the tools of concern and coercion in the hegemony in Murung Raya became a weapon for local elites to strengthen control to remove obstacles in the process of spreading discourse to the community. In addition, this tool is also used to strengthen the informal consensus on external power groups.

Table 5. Reward and Punishment of Ruling Elites to Society

\begin{tabular}{|c|c|c|}
\hline The Instrument of Power & Concern and Coercion & $\begin{array}{l}\text { The Instrument of } \\
\text { Power }\end{array}$ \\
\hline Agriculture Department & $\begin{array}{l}\text { Get facilities and tool for } \\
\text { Agricultural such as fertilizer }\end{array}$ & $\begin{array}{l}\text { matters of agricultural } \\
\text { assistance will be more } \\
\text { complicated }\end{array}$ \\
\hline Labor Department & $\begin{array}{l}\text { Get recommendation to join to the } \\
\text { office and company }\end{array}$ & $\begin{array}{l}\text { Get banned to join the } \\
\text { office or company }\end{array}$ \\
\hline Regional Personnel Institution & $\begin{array}{l}\text { Get Assisted in the personnel } \\
\text { transfer process and certification } \\
\text { matters }\end{array}$ & $\begin{array}{l}\text { Transferred to distant } \\
\text { territories and made } \\
\text { difficult in dealing with } \\
\text { promotions }\end{array}$ \\
\hline Dayak Council & Get incentives & Got change \\
\hline $\begin{array}{l}\text { government apparatus at the village, } \\
\text { kelurahan, sub-district to district } \\
\text { levels }\end{array}$ & $\begin{array}{l}\text { get easier access to become } \\
\text { honorary staff }\end{array}$ & $\begin{array}{l}\text { Get Difficulties to } \\
\text { become honorary staff }\end{array}$ \\
\hline
\end{tabular}

Source: Primary researcher data

The use of those instrument was based on the interest of ruling elite to push and decrease differences and also to facilitate the process of spreading discourse to the community. Hegemony works by creating ways of thinking and truth in society. Dissemination of discourse is the basis of efforts to form mindsets and social paradigms in society. The production of discourse by ruling elite in Murung Raya Regency has used the principle of conformity with community norms and habits. Then the massive spread of discourse is also determined by the social, political, and psychological conditions of the people being targeted.

Table 6. Discourse that spread in Murung Raya People and Stakeholder

\begin{tabular}{llll}
\hline Targeted & Scope & Discourses & \\
\hline $\begin{array}{l}\text { Bakumpai Figures and Centre } \\
\text { KKB Organizations }\end{array}$ & $\begin{array}{l}\text { Regency } \\
\text { Murung Raya }\end{array}$ & $\begin{array}{l}\text { Discourse about family ties of } \\
\text { ancestors and avoids religious } \\
\text { differences }\end{array}$ \\
Politician and entrepreneur & $\begin{array}{l}\text { Regency } \\
\text { Murung Raya }\end{array}$ & of & $\begin{array}{l}\text { Winning calculation and project } \\
\text { distribution }\end{array}$ \\
Farmers & $\begin{array}{l}\text { Regency } \\
\text { Murung Raya }\end{array}$ & $\begin{array}{l}\text { of } \\
\text { access to fertilizer assistance and the } \\
\text { formation of farmer groups }\end{array}$
\end{tabular}




\begin{tabular}{|c|c|c|}
\hline Bachelor and their Parents & $\begin{array}{l}\text { Regency of } \\
\text { Murung Raya }\end{array}$ & $\begin{array}{l}\text { appreciation for scholars and access to } \\
\text { Honorary work }\end{array}$ \\
\hline Villagers & $\begin{array}{l}\text { Regency of } \\
\text { Murung Raya }\end{array}$ & $\begin{array}{l}\text { protecting farmers and granting access } \\
\text { to company entry and rising rubber } \\
\text { prices }\end{array}$ \\
\hline Indigenous People & $\begin{array}{l}\text { Regency of Barito } \\
\text { Hulu }\end{array}$ & $\begin{array}{l}\text { support the revitalization of adat and } \\
\text { give them incentives }\end{array}$ \\
\hline
\end{tabular}

Source: Primary researcher data

The success of delivering messages or discourses of dominant groups (power) is influenced by mediators who are able to directly or indirectly "instill" discourse of hegemony to influence the way of thinking, acting and truth in society. In the concept of mediator hegemony known as traditional intellectuals and organic intellectuals. The hegemony in Murung Raya Regency uses mediators from various stakeholders and is adapted to the place and target of the discourse to be disseminated. For more details, see the following table:

Table 7. Mediator List and Targeted of Discourse in Murung Raya

\begin{tabular}{lll}
\hline Mediator & Targeted & Purposed \\
\hline Bureaucrat officials & $\begin{array}{l}\text { State employees } \\
\text { and civil servants } \\
\text { Village Apparatus } \\
\text { and Society }\end{array}$ & $\begin{array}{l}\text { In order to support Ruling Elites } \\
\text { In order to support Ruling Elites }\end{array}$ \\
Bakumpai Figures & Bakumpai People & $\begin{array}{l}\text { so that the ruling elite gets external } \\
\text { support }\end{array}$ \\
Adat Figures & Adat People & $\begin{array}{l}\text { Maximizing the support of indigenous } \\
\text { peoples and the consolidation of } \\
\text { networks that are commonly used }\end{array}$ \\
Head of Big Family & Family & $\begin{array}{l}\text { so that the ruling elite gets big family } \\
\text { support } \\
\text { Reducing the issue of religious } \\
\text { differences }\end{array}$ \\
\hline Banjar Figures & Association &
\end{tabular}

Source: Primary researcher data

In addition to maximizing support through mediators in spreading discourse, the ruling elite uses populist strategies such as visiting villages, accompanied by the head of the office, village head, traditional leader, damang and various local figures, then greets everyone in the house. The ruling elite exploits the existing problems in the community to get sympathy and support in the community.

The strategy of the regent and the ruling elite in gaining empathy and emotional relations aims to get attention and love from the people and to make people accept them as the ruling elites easily. Emotional relations between the ruling elite and the community will facilitate the inclusion and inculcation of perspectives that contain the interests of the authorities. By this way the hegemony will work in peace and harmony without any kind of rejection even from elites, political party, even from people. The consensus among elites and other stakeholder has built their political position stronger and settled their domination in Murung Raya. 


\section{Conclusion}

The transformation of democracy and the contention of Local politics in Indonesia has been change after the fall of new order era. The reformation era has brought the concept of decentralization and local autonomy to strengthen the local governance. The central of government will delegate their authority to local government to increase the effectiveness and efficient of democracy in society and also giving more power to head of region in making decision and policy.

Institutional change in the leader selection mechanism from a centralized-authoritarian to a decentralized and democratized system may lead to an unintended consequence. The new mechanism of head of government lection opens a window of opportunity for local elites to consolidate and expand their power base by utilizing undemocratic methods[1]. Hegemony is new method for local elites to establish their political settlement in subnational government by local democracy or direct election. Hegemony in Murung Raya Regency has been showed that the structure of domination not by ideology or value and norms but actually happens by a compromise of interests for the short-term political interests. Not only for political elite interest but also for people short-term interest. Hegemony in Murung Raya also showed that the inculcation of meaning and values to the community in Murung Raya Regency is not only an intellectual and cultural product but part of the product of emotional ties, empathy, and love that is always tucked in by the elites.

\section{References}

[1] Kenawas, Y. C. :The Rise of Political Dynasties in a Democratic Society EDGS Work. Pap. Arryman Fellow. pp. 1-58 (2015)

[2] Krouse, R. W. : Polyarchy \& Participation: The Changing Democratic Theory of Robert Dahl. Polity, vol. 14.pp. 441-463 (1982)

[3] Winters, J. A. : Oligarchy and democracy in Indonesia, Indonesia.pp. 11-33 (2013)

[4] Buehler, M. .: Elite Competition and Changing State-Society Relations: Shari'a Policymaking in Indonesia, Beyond Oligarchy, vol. 1.pp. 157-176 (2018)

[5] Arin K. Y. and K. Y. Arin.: Elite Theory, Think Tanks.pp. 45-49 (2014)

[6] Bassiouni C. : Democracy : Its Principles and Achievement Democracy (1998)

[7] Olsen M. E.: Elite Integration in Stable Democracies, Power Mod. Soc., Vol. 7.pp.196-209 (2019)

[8] Charles Tilly, Democracy. Cambridge.

[9] Duru, O. W. C. : The Relationship Between The Elite Theory Of Politics And The Concept of Liberal Democracy pp. 1-19.

[10] J. Lull.: Hegemony22 (1995)

[11] Mouffe and E. Laclau.: Hegemony and Socialist Strategy:Towards a Radical Democratic Politics Second Edition Ernesto Laclau (1985)

[12] Lears, T. J. J. : The Concept of Cultural Hegemony : Problems and Possibilities Author Jackson Lears Source: The American Historical Review, Vol . 90.pp . 567-593 (2016)

[13] Thomas, P. : The ambivalent state and the media in India: Between elite domination and the public interest, Int. J. Commun., Vol. 8.pp. 466-482 (2014)

[14] Bryman, A. : Social Research Methods (4th Edition) by Alan Bryman Abhigyan,Vol. 32.pp.77 (2015)

[15] Gramsci, A. : Selections from the Prison Notebooks (London: Wishart Publications)

[16] Patria, Nezar \& Arief, A.:Antonio Gramsci Negara \& Hegemoni (Yogyakarta: Pustaka Pelajar)

[17] Hatta, M. Demokrasi Kita (Bandung: Sega Arsy) (2014)

[18] Huntington, S. P. .: The Third Wave. Democratization in the Late Twentieth Century (Norman: University of Oklahoma Press) (1991) 
[19] Ratnawati, D. A.: Modul Teori Politik, politik lokal dan otonomidaerah. (Yogyakarta: sekolah pascasarjana Universitas Gadjah Mada) (2005)

[20] Kaisiepo, M. : Antara hegemoni dan eksistensi (Jakarta: Rajawali Pers) (2004)

[21] Hilmi, M. : Agama Dan Demokrasi (Jakarta: Kompas) (2014)

[22] Marx, Karl \& Angel, F. : Manifesto Partai Komunis (Jakarta: Ultimus)

[23] Latif, Y. : Negara Paripurna (Jakarta: PT Gramedia Pustaka Utama) (2011)

[24] Natsir, M. : Islam Sebagai Dasar Negara (Jakarta: Sega Arsy) (2014)

[25] Effendi, C. : Indonesia's decentralization policy after seventeen years: two contending approaches.pp.1-2 (2017)

[26] Budiarjo, M.: Dasar-Dasar Ilmu Politik (Jakarta: Gramedia) (2009)

[27] Gaxie, D. : Democracy and elites, Corvinus J. Sociol. Soc. Policy, Vol. 8.pp. 17-37 (2017)

[28] Beri and C. Schneickert,: Social Structure and Globalization of Political and Economic Elites in India.pp. 115-130 (2010)

[29] Volk,D: The Circulation of Elites in Twentieth Century American History: The New Deal as Case Study (1976)

[30] Odubajo, B. T \& Alabi.: The elite factor in Nigeria's political -power Dynamics,J. Stud. Soc. Sci., Vol. 8.pp. 121-139 (2014)

[31] Mustafa Delican.: Elite theories of pa reto, mosca and michels Dog (1935)

[32] Jones, C. : Elite democracy Political competition and voter opinion in the 2010 Australian Federal election (1989)

[33] Schmitter P. C. and E. Professor.: Democratization and political elites or political elites and democratization or the process of democratization and the role of elites or the role of elites in democratization or democratization: the role of elites.pp. 1-22 (2016) 